\title{
Liquefaction Analysis Based on Liquefaction Potential Index Method in Prambanan Temple Complex of Jogjakarta
}

\author{
Lisa Fitriyana $^{1 *}$ and Bayu Prasetyo Afandi ${ }^{2}$ \\ ${ }^{1}$ Civil Engineering Study Program, Faculty of Engineering, Sultan Agung Islamic University, Semarang, \\ Indonesia \\ ${ }^{2}$ Student of Civil Engineering Master Program, Sultan Agung Islamic University, Sultan Agung Islamic \\ University, Semarang, Indonesia \\ * Corresponding author: lisa.fitriyana@unissula.ac.id
}

(Received: November 28 ${ }^{\text {th }}, 2019$; Revised: October $4^{\text {th }} 2020$; Accepted: October $14^{\text {th }} 2020$ )

\begin{abstract}
Prambanan Temple is a cultural heritage located in Jogjakarta. Tectonically, the Special Region of Jogjakarta and its surroundings are an area with a fairly high level of seismic activity in Indonesia. Geotechnically, the soil in Jogjakarta is sandy with similar gradation. The thickness of the sand ranges from $-50 \mathrm{~m}$ to $-60 \mathrm{~m}$. Whereas, the ground water level is located at a depth of $-12 \mathrm{~m}$ during dry season and in rainy season, it rises from $-6 \mathrm{~m}$ to $-4 \mathrm{~m}$. The impact of soil types and the high Ground Water Level (GWL) allow it for liquidation to occur during an earthquake. This study was conducted using liquefaction analysis, through Liquefaction Potential Index (LPI) method with ground water level variations. Before analyzing the liquefaction using LPI method, Peak Ground Acceleration (PGA) methods were used, and analysis could then be done through Cyclic Resistance Ratio (CRR) and Cyclic Stress Ratio (CSR) to obtain safety factors and the Liquefaction Potential Index analysis was then conducted. To analyze this liquefaction, earthquake data from 2004 to 2019 and the results of the SPT field test at the Prambanan Temple were needed. From the liquefaction potential analysis through Liquefaction Potential Index (LPI), the results showed that in CSR Seed \& Idriss (1971) and CRR Tokimatsu \& Yoshimi (1983), GWL $1 \mathrm{~m}$ at depths from $4.5 \mathrm{~m}$ and above, the potential of liquefaction occurrence was high. The largest PGA value was obtained based on the Matsuchka (1980) method on May 26, 2006 which was 0.102.
\end{abstract}

Keywords: liquefaction; peak ground acceleration; liquefaction potential index

\section{Introduction}

\subsection{Background of the Study}

The liquefaction phenomenon occurs when a layer of water-saturated soil undergoes a decrease in strength due to loss of shear resistance by an increase in soil pore water stress that occurs during an earthquake [2]. The soil undergoes a change in behavior to become liquid-like so that a structural collapse occurs. Some earthquakes causing liquefaction were the 2004 Aceh and Nias earthquake, the Jogjakarta earthquake in 2006, Padang in 2008 [3] and the latest one in Palu in 2018 [4].

Prambanan Temple is a cultural heritage located in Jogjakarta. Tectonically, the Special Region of Jogjakarta and its surroundings are an area with a fairly high level of seismic activity in Indonesia [1]. Geotechnically, the soil in Jogjakarta is sandy with similar gradation which is quite thick. The thickness of the sand ranges from $-50 \mathrm{~m}$ to $-60 \mathrm{~m}$. Whereas, the ground water level (GWL) is located at a depth of $-12 \mathrm{~m}$ during the dry season and in the rainy season, it rises from 
$-6 \mathrm{~m}$ to $-4 \mathrm{~m}$. The impact of soil types and the high GWL allow it for liquidation to occur during an earthquake.

The effect of Peak Ground Acceleration (PGA) and GWL is very large on the liquefaction potential [5]. Peak Ground Acceleration (PGA) is the acceleration of an earthquake above the ground and is very important for earthquake engineering input parameters [6]. Therefore, it is important to analyze Peak Ground Acceleration (PGA) with GWL variations on the liquefaction potential in Prambanan Temple Complex.

\subsection{Liquefaction}

Liquefaction occurs when a layer of water-saturated sand undergoes vibrations, the sand will solidify and the volume decreases, if the water is not drained, the pore water stress will increase and be the same as normal stress, consequently the effective stress value that supports the building becomes zero and the sand forms liquid-like which causes the structure it supports to sink [7].

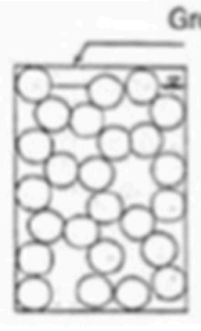

(a) before Liquifaction
Ground Surtace

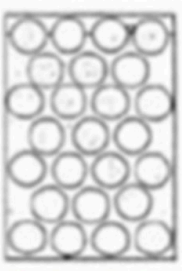

(b) during

Liquifaction

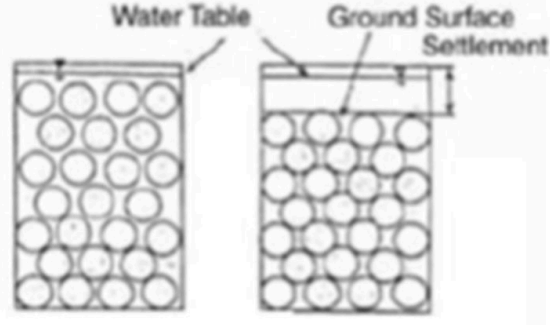

(c) compression

after Liquifaction

(d) deformed

Fig. 1. Mechanisms of the liquefaction occurrence [8]

\section{3. liquefaction parameter}

According to Day [9] the triggers for liquefaction include:

a. Earthquake intensity and duration.

b. The ratio of the amplitude of vertical and horizontal movement at ground level.

c. Type of soil.

d. Relative soil density.

e. Placement and environmental conditions.

f. Soil grain size.

g. Drainage conditions.

h. Pressure bridle.

i. Soil particle

j. Soil age and cementation.

\section{Research Methods}

To carry out liquefaction analysis, the Liquefaction Potential index (LPI) method required field test data, namely NSPT and GWL at various points in the research location at the Prambanan Temple complex of Jogjakarta. In addition to the NSPT and GWL values, Jogjakarta earthquake data from 2004 to 2019 were also needed.[10]. In the liquefaction analysis, variations in GWL depth, namely $1 \mathrm{~m}, 3 \mathrm{~m}$ and $10 \mathrm{~m}$, were made.

\subsection{Data Processing}

1. Firstly, the Peak Ground Acceleration (PGA) was calculated using empirical methods, namely Matsuchka [11] and Campbell [12] methods.

a. Matsuchka (1980) produces relationships according to Eq. (1)

$$
a_{\max }=\frac{119 \times e^{0.81 M}}{(R+25)^{1.15}}
$$


b. Campbell (1981) uses the world's earthquake data to develop the human equation for accelerating average land surface peaks for locations within $50 \mathrm{~km}$ of the fault location with earthquake sizes of 5.0 to 7.7 with Eq. (2)

$$
\ln a_{\max }=-4.141+0.868 M-1.09 \ln \left(R+0.606^{0.7 M}\right)
$$

$a_{\max }$ is the peak acceleration of the ground surface $\left(\mathrm{cm} / \mathrm{s}^{2}\right), \mathrm{R}$ Is the distance from the earthquake epicenter $(\mathrm{km})$ and $\mathrm{M}$ is the local magnitude of the earthquake on Richter Scale.

2. CSR (Cyclic Stress Ratio) is assumed that a small element of soil undergoes shear stress due to the inertia force of the above ground column. Based on Seed and Idris [13] in Eq. (3):

$$
C S R=\frac{\tau_{c y c}}{\sigma_{V 0}}=0.65 \times r_{d} \times\left(\frac{\sigma_{V 0}}{\sigma_{V 0}}\right) \times r_{d}
$$

3. CRR (Cyclic Resistance Ratio) is the CSR value needed to calculate the occurrence of liquefaction in a ground element with a certain density, and its value can be determined by SPT (Standard Penetration Test) based on Yoshimi and Tokimatssu [14] in Eq. (4)

$$
C R R=a \cdot C_{r}\left[\frac{16 \sqrt{N_{\alpha}}}{100}+\left(\frac{16 \sqrt{N_{\alpha}}}{C_{a}}\right)^{n}\right]
$$

4. Liquefaction Analysis through the Liquefaction Potential Index (LPI) Method. This method is mostly appropriate for determining the level of potential damage / severity from the liquefaction analysis developed by Iwasaki et al.[15]. Analysis with this method can simultaneously be done with the liquefaction analysis through simplified procedure with Eq. (5).

$$
L P I=\int_{0}^{20 \mathrm{~m}} F w(z) d z
$$

Where:

LPI : Liquefaction Potential Index Value

$F \quad: \quad$ The severity of a layer in the liquefaction analysis, where $F=(1-S F)$ for $S F<1$, and $F=0$ for $S F>1$

$w(z)$ : The depth weighting factor, where: $w(z)$ 10-0,5z, where $z$ is the depth of analysis, a maximum of 20 meters

Iwasaki et al. [15] states that, if:

a. LPI $<5$, the location is categorized as low potential for liquefaction to occur so that creates manifestation on ground level.

b. LPI 5-15, the location is categorized to have a high potential for liquefaction to occur.

c. LPI $>15$, the location is categorized as very potential for liquefaction to occur with high severity, so that symptoms of liquefaction can be detected above ground level.

\section{Results and Discussion}

\subsection{The Calculation of Peak Ground Acceleration (PGA)}

According to the equations (2.1) and (2.2), the results of the calculation of Peak Ground Acceleration (PGA) based on BMKG data are shown in Table 1.

Table 1. PGA values

\begin{tabular}{cc}
\hline Method & PGA Values \\
\hline Matsuchka & 0.102 \\
Campbell & 0.084 \\
\hline
\end{tabular}

The largest PGA value obtained from the GWLsuchka method was 0.102 and used as a reference for further calculations. 


\subsection{The Calculation of CRR and CSR}

The Cyclic Resistance Ratio (CRR) and Cyclic Stress Ratio (CSR) values were used to obtain the Safety Factor $(S F)$ to be used in calculating the LPI (Liquefaction Potential Index). SF is a comparison between CRR and CSR values. The calculations of CRR and CSR were done by varying the GWL at a depth of $1 \mathrm{~m}, 3 \mathrm{~m}$, and $10 \mathrm{~m}$. From the results of the calculations in Eq (3) and Eq (4) was obtained the following chart:

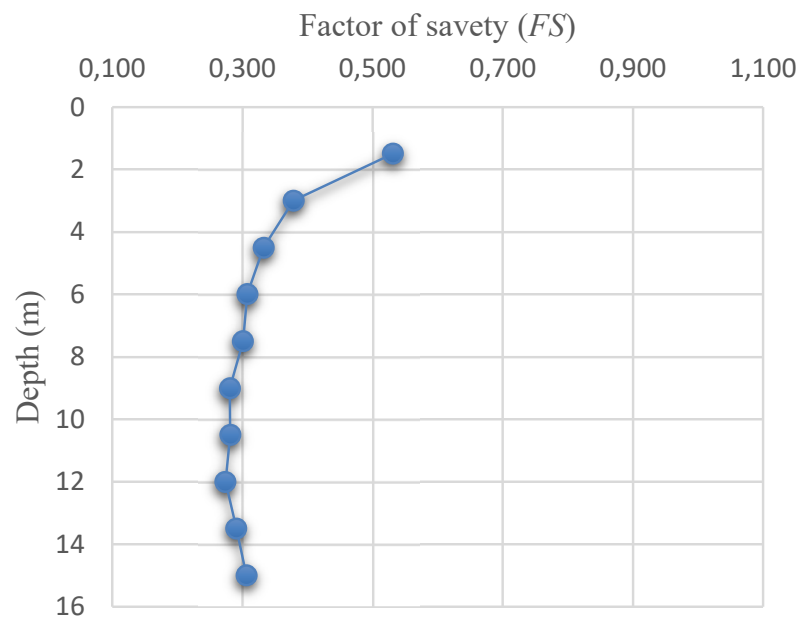

Fig. 2. The Chart of FS CSR Seed and Idriss (1971) values by Tokimatsu and Yoshimi (1983) with $1 \mathrm{~m}$ water level

In Fig. 2, the GWL at a depth of $1 \mathrm{~m}$ can be seen. From the $S F$ value, it can be seen that the largest $S F$ is located at a depth of above $1 \mathrm{~m}$ (not submerged in water) which means that the $S F$ under the GWL is smaller because it is submerged (saturated), the higher the $S F$ value is, the less potential for liquidation will be.

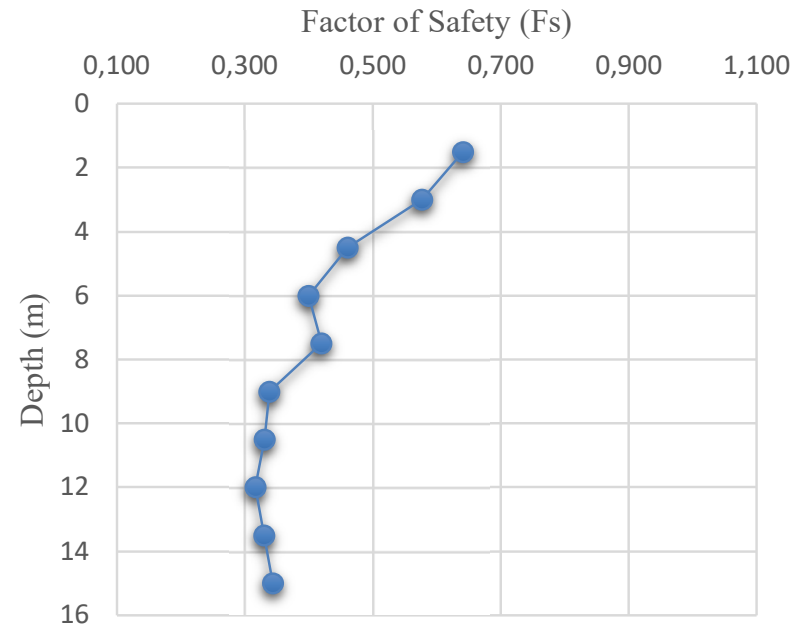

Fig. 3. The Chart of FS CSR Seed and Idriss (1971) values by Tokimatsu and Yoshimi (1983) with $3 \mathrm{~m}$ water level

Based on Fig. 3, the GWL at a depth of $3 \mathrm{~m}$ can be seen, while Fig. 4, the GWL is seen at a depth of $10 \mathrm{~m}$. Same thing is also seen in Fig. 2 that the largest SF is found at a depth of not submerged in water. The deeper the location of the ground water level (GWL), it appears that the effect of liquefaction never happens, conversely the shallower (height) location of ground water level, the effect of liquefaction tends to occur as long as the PGA value is the same. 


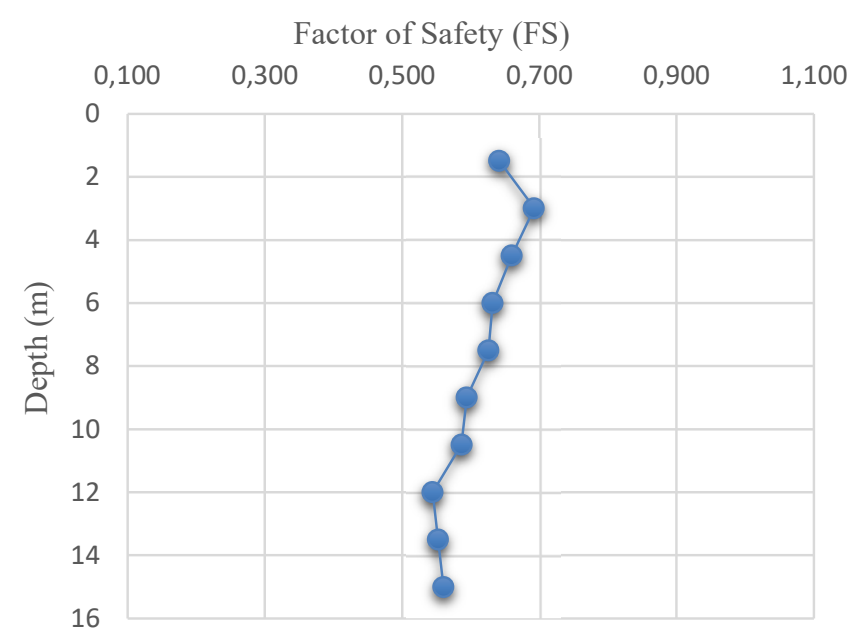

Fig. 4. The Chart of FS CSR Seed and Idriss (1971) values by Tokimatsu and Yoshimi (1983) with $10 \mathrm{~m}$ water level

\subsection{The Calculation of Liquefaction Potential Index (LPI)}

The analysis of potential liquefaction can be seen from the Liquefaction Potential Index used in the equation (2.5). The results of the CSR, CRR and $S F$ calculations were used to conduct LPI calculations which can be seen as in the Table 2, Table 3, and Table 4.

Table 2. LPI (CSR Seed \& Idriss, 1971 and CRR Tokimatsu \& Yoshimi, 1983 GWL 1 m)

\begin{tabular}{cccccc}
\hline Depth (m) & $\boldsymbol{F S}$ & $\boldsymbol{F}$ & $\boldsymbol{w}(\boldsymbol{z})$ & LPI & Description \\
\hline 1.5 & 0.331 & 0.469 & 9.25 & 5.186 & potential occurrence of liquefaction is high \\
\hline 3 & 0.378 & 0.622 & 8.5 & 5.285 & potential occurrence of liquefaction is high \\
\hline 4.5 & 0.333 & 0.667 & 7.75 & 5.172 & potential occurrence of liquefaction is high \\
\hline 6 & 0.307 & 0.693 & 7 & 4.850 & potential occurrence of liquefaction is low \\
\hline 7.5 & 0.301 & 0.699 & 6.25 & 4.372 & potential occurrence of liquefaction is low \\
\hline 9 & 0.281 & 0.719 & 5.5 & 3.954 & potential occurrence of liquefaction is low \\
\hline 10.5 & 0.282 & 0.718 & 4.75 & 3.412 & potential occurrence of liquefaction is low \\
\hline 12 & 0.274 & 0.726 & 4 & 2.904 & potential occurrence of liquefaction is low \\
\hline 13.5 & 0.290 & 0.710 & 3.25 & 2.306 & potential occurrence of liquefaction is low \\
\hline 15 & 0.306 & 0.694 & 2.5 & 1.735 & potential occurrence of liquefaction is low \\
\hline
\end{tabular}

Table 3. LPI (CSR Seed \& Idriss, 1971 dan CRR Tokimatsu \& Yoshimi, 1983 GWL 3 m)

\begin{tabular}{cccccc}
\hline Depth $(\mathbf{m})$ & $\boldsymbol{F S}$ & $\boldsymbol{F}$ & $\boldsymbol{w}(\boldsymbol{z})$ & LPI & Description \\
\hline 1.5 & 0.642 & 0.358 & 9.25 & 3.315 & potential occurrence of liquefaction is low \\
\hline 3 & 0.577 & 0.423 & 8.5 & 3.596 & potential occurrence of liquefaction is low \\
\hline 4.5 & 0.461 & 0.539 & 7.75 & 4.177 & potential occurrence of liquefaction is low \\
\hline 6 & 0.400 & 0.600 & 7 & 4.203 & potential occurrence of liquefaction is low \\
\hline 7.5 & 0.420 & 0.580 & 6.25 & 3.627 & potential occurrence of liquefaction is low \\
\hline
\end{tabular}




\begin{tabular}{cccccc}
\hline Depth $(\mathbf{m})$ & $\boldsymbol{F S}$ & $\boldsymbol{F}$ & $\boldsymbol{w}(\boldsymbol{z})$ & LPI & Description \\
\hline 9 & 0.339 & 0.661 & 5.5 & 3.638 & potential occurrence of liquefaction is low \\
\hline 10.5 & 0.331 & 0.669 & 4.75 & 3.176 & potential occurrence of liquefaction is low \\
\hline 12 & 0.317 & 0.683 & 4 & 2.733 & potential occurrence of liquefaction is low \\
\hline 13.5 & 0.331 & 0.669 & 3.25 & 2.175 & potential occurrence of liquefaction is low \\
\hline 15 & 0.344 & 0.656 & 2.5 & 1.640 & potential occurrence of liquefaction is low \\
\hline
\end{tabular}

Table 4. LPI (CSR Seed \& Idriss, 1971 dan CRR Tokimatsu \& Yoshimi, 1983 GWL 10 m)

\begin{tabular}{cccccc}
\hline Depth $(\mathbf{m})$ & $\boldsymbol{F S}$ & $\boldsymbol{F}$ & $\boldsymbol{w}(\boldsymbol{z})$ & LPI & Description \\
\hline 1.5 & 0.642 & 0.358 & 9.25 & 3.315 & potential occurrence of liquefaction is low \\
\hline 3 & 0.577 & 0.423 & 8.5 & 3.596 & potential occurrence of liquefaction is low \\
\hline 4.5 & 0.461 & 0.539 & 7.75 & 4.177 & potential occurrence of liquefaction is low \\
\hline 6 & 0.400 & 0.600 & 7 & 4.203 & potential occurrence of liquefaction is low \\
\hline 7.5 & 0.420 & 0.580 & 6.25 & 3.627 & potential occurrence of liquefaction is low \\
\hline 9 & 0.339 & 0.661 & 5.5 & 3.638 & potential occurrence of liquefaction is low \\
\hline 10.5 & 0.331 & 0.669 & 4.75 & 3.176 & potential occurrence of liquefaction is low \\
\hline 12 & 0.317 & 0.683 & 4 & 2.733 & potential occurrence of liquefaction is low \\
\hline 13.5 & 0.331 & 0.669 & 3.25 & 2.175 & potential occurrence of liquefaction is low \\
\hline 15 & 0.344 & 0.656 & 2.5 & 1.640 & potential occurrence of liquefaction is low \\
\hline
\end{tabular}

From the results of the Liquefaction Potential Index (LPI) calculation, the results showed that in Table 2, the ground water level at a depth of $1 \mathrm{~m}$ was categorized as high liquefaction potential, at a depth of $1.5 \mathrm{~m}$ to $4.5 \mathrm{~m}$ was moderate, while at a depth of 4.5 to $15 \mathrm{~m}$ potential was low liquefaction. While in Table 3, the ground water level at a depth of $3 \mathrm{~m}$ and Table 4, the ground water level of $10 \mathrm{~m}$ was categorized as low liquefaction.

\section{Conclusions}

a. The largest PGA value using Matsuchka (1980) method on May 26, 2006 is 0.102

b. From the analysis of liquefaction potential with the Liquefaction Potential Index (LPI), it can be seen that in CSR Seed \& Idriss (1971) and CRR Tokimatsu \& Yoshimi (1983), the ground water level $1 \mathrm{~m}$ at depths from $4.5 \mathrm{~m}$ above is high in the potential occurrence of liquefaction. While, the Liquefaction Potential Index (LPI) of ground water level of $3 \mathrm{~m}$ and $10 \mathrm{~m}$ is low

c. The deeper the location of the ground water level (GWL) is, it appears that the effect of liquefaction never happens, conversely the shallower (height) location of ground water level is, the effect of liquefaction tends to occur as long as the PGA value is the same

d. Changes in ground water level greatly affect the value of a safe factor for liquefaction and the earthquake distance and magnitude scale is closer

\section{References}

[1] Team for Detailed Engineering Design (DED) Compilation, 2012, Technical Study Activity for the Preservation of Siwa Temple, Prambanan Temple Complex, BPCB Yogyakarta.

[2] Tohari., A., 2007, Study of liquefaction and Water Resources, Research Center for Geotechnology, LIPI. 
[3] Soebowo, E., Tohari, A., \& Sarah, D., 2014, Identification of Potential liquefaction Due to Earthquake in Sumatra, Java and Bali, Proceedings of the Seminar on Role of Geotechnology Research for Supporting Sustainable Development in Indonesia, Research Center for Geotechnology LIPI.

[4] Mangunpraja, DM and Pratiningsih, Anik, 2019, The analysis of Soil Improvement as a Form of Liquefaction Disaster Mitigation That Can Be Applied by Communities in Palu, Jurnal Mitra Teknik Sipil, Vol. 2, No. 4, November 2019: pp. 95-104

[5] Kuningsih, TW, Rifa'i, A, and Suryalelono, KB, 2017, Analysis of the Resilience of the Prambanan Temple Base Soil Against the Threat of Liquefaction Based on Simplified Procedure, Journal of Polytechnology Vol. 16 No.1 January 2017

[6] Wibowo, NB and Sembri, JN, 2016, Analysis of Peak Ground Acceleration (PGA) and Earthquake Intensity based on 1981 - 2014 Earthquake Data in Bantul Regency, Yogyakarta, Indonesian Journal of Applied Physics (2016) Vol. 6 No.1 Page 65

[7] Soebowo, E., Tohari, A., \& Sarah, D., 2007, Study of the Potential of Liquefaction in the Opak Patalan-Bantul Jogjakarta Fault Zone, Proceedings of the Seminar on Geotechnology Contribution of Earth Sciences in Sustainable Development, Research Center for Geotechnology-LIPI.

[8] Mase, L.Z., 2013, Analysis of the Potential of Liquefaction in the Opak Imogiri River, Yogyakarta Special Region (Experimental Study and Empirical Analysis), Thesis, Department of Civil (Geotechnical) and Environmental Engineering, Gadjah Mada University.

[9] Day, R.W., 2002, Geotechnical Earthquake Engineering Handbook, McGraw-Hill, New York, USA.

[10] http://www.bmkg.go.id/BMKG_Pusat/Gempabumi_-Tsunami/Gempabumi.\%20bmkg (Accessed 18 April 2019)

[11] Matuschka, T. 1980. Assessment of seismic hazards in New Zealand. Tech. rept. 222. Department of Civil Engineering, School of Engineering, University of Auckland. Reported in Stafford (2006).

[12] Campbell K. W, 1981, Near-sorce Attenuation of Peak Horizontal Acceleration, Bulletin of the Seismological society of America, Vol.71, No.6, pp.2039- 2070

[13] Seed, H.B., and Idriss, I.M., 1971, Simplified Procedure for Evaluation Soil Liquefaction Potential, Journal of Soil Mechanics and Foundation, Division, ASCE, vol. 97, No.9, pp 1249-1273.

[14] Tokimatsu, K., dan Yoshimi, Y., 1983, Empirical Correlation of Soil Liquefaction Based on SPT Values and Fines Content, Soils and Foundations, Vol.23, No.4, 56-74.

[15] Iwasaki, T., Arakawa, T.,\& Tokida, K., 1984, Simplified Procedures for Assessing Soil Liquefaction during Earthuakes, Soil Dynamics and Earthquake Engineering, Vol.3, Southampton, hal. 49-58 